\title{
PENGEMBANGAN RUMFIS (RUMUS FISIKA) BERBASIS PROGRAM MATLAB PADA MATERI SUHU DAN KALOR UNTUK MENINGKATKAN MOTIVASI BELAJAR SISWA SMPN 2 LABUAPI KELAS VII TAHUN AJARAN 2017/2018
}

\author{
Nurul Zulmi ${ }^{1^{*}}$, Ni Wayan Sri Darmayanti ${ }^{2}$, Zulkarnain $^{3}$ \\ ${ }^{1 *}$ Mahasiswa Sarjana Program Studi Pendidikan Fisika Universitas Muhammadiyah Mataram \\ ${ }^{2 \& 3}$ Dosen Progran Studi Pendidikan Fisika Universitas Muhammadiyah Mataram \\ Corresponding author : \\ E-mail : nurulzulmi95@gmail.com
}

Diterima 2 Juli 2018, Disetujui 5 Juli 2018

\begin{abstract}
ABSTRAK
Perkembangan teknologi informasi telah mempengaruhi pengunaan jenis media sebagai alat bantu dalam proses pembelajaran, permasalahan yang muncul adalah bagaimana seorang guru mampu menciptakan proses pembelajaran yang menyenangkan sehingga motivasi belajar siswa meningkat melalui pemilihan dan penggunaan media pembelajaran yang tepat. Media pembelajaran mempunyai peranan yang sama pentingnya dengan faktor-faktor pendidikan yang lain, namun kurang diperhatikan oleh guru. Padahal kehadiran media dalam pembelajaran juga memberikan dampak positif bagi pengajaran dalam penyajian informasi yang akan diberikan terhadap siswa. Penelitian ini bertujuan untuk mengetahui pengembangan RUMFIS berbasis program Matlab pada materi Suhu dan Kalor khususnya pada cakupan materi singkat serta rumusnya dapat meningkatkan motivasi belajar siswa SMP Negeri 2 Labuapi kelas VII tahun ajaran 2017/2018. Penelitian ini menggunakan metode R\&D (Reserch and Development). Populasi dalam penelitian ini adalah peserta didik kelas VII SMP Negeri 2 Labuapi yang terdiri dari 1 kelas dan berjumlah 20 orang. Model pengembangan yang digunakan adalah Borg dan Gall yang terdiri dari 10 langkah yang harus diikuti untuk menghasilkan produk berupa RUMFIS berbasis program Matlab. Data diperoleh melalui angket. Teknik analisis data yang digunakan adalah deskriptif kualitatif untuk mengukur motivasi belajar siswa. Dari hasil penelitian diketahui bahwa RUMFIS berbasis program Matlab pada materi Suhu dan Kalor dapat meningkatkan motivasi belajar siswa. Hal ini berdasarkan pada peresentase motivasi sebelum menggunakan media RUMFIS sebesar $51 \%$ dan mengalami peningkatan menjadi $72 \%$ setelah menggunakan media RUMFIS dengan gain sebesar 0,43 dalam kategori sedang.
\end{abstract}

Kata Kunci: Pengembangan RUMFIS, Program Matlab, Motivasi Belajar.

\section{PENDAHULUAN}

Pendidikan adalah modal awal yang harus dipenuhi setiap manusia untuk menghadapi kemajuan zaman guna meraih masa depan dan berperan dalam mengubah karakter manusia sehingga dalam pelaksanaan pendidikan, hal yang terkait dengan proses pengajaran, metode, media, dan cara pengajaran guru seharusnya lebih diperhatikan guna mewujudkan tujuan pendidikan. Selain itu, siswa seharusnya mendapatkan bimbingan, dorongan dan peluang yang memadai untuk belajar dan mempelajari hal yang terkait dalam kehidupannya baik dari guru, keluarga dan lingkungan masyarakat (Nababa, 2016).

Guru memiliki beragam tugas yang berimplementasi dalam bentuk pengabdian. Tugas tersebut meliputi bidang profesi, bidang kemanusiaan dan bidang kemasyarakatan. Tugas guru sebagai profesi yang mendidik, mengajar, dan melatih. Disekolah guru membantu peserta didik untuk mempelajari sesuatu yang belum diketahuinya, membentuk kopetensi dan memahami materi standar yang dipelajari (Darma, dkk, 2017). Guru sebagai pendidik harus mampu menyiapkan diri untuk menghadapi perkembangan masyarakat dengan berbagai penguasaan informasi dan teknologi saat ini.

Seiring dengan kemajuan sistem Teknologi Informasi ( $\mathrm{TI})$, dunia pendidikan senantiasa bergerak maju secara dinamis, khususnya untuk menciptakan media, metode dan materi pendidikan yang semakin menarik, interaktif dan komprehensif. Oleh karena itu sektor pendidikan harus mampu memanfaatkan Teknologi Informasi (TI) untuk mengembangkan sistem pendidikan (Viajayani, dkk, 2013).

$$
\text { Melihat perkembangan teknologi }
$$
informasi (IT) yang demikian pesat sekarang ini, sehingga perlu antisipasi oleh guru untuk 
menyikapinya. Salah satu hal yang perlu dilakukan oleh guru adalah mengkaitkan materi yang diajarkan dengan penerapan dalam pembuatan media pembelajaran berbasis komputer (Sitanggag, 2016).

Peran media yang digunakan dapat menghidupkan suasana belajar siswa, mampu membantu siswa dalam memahami pembelajaran dan sebagai alat bantu untuk memberikan perangsangan pada siswa. Kehadiran media dalam pembelajaran juga memberikan dampak bagi pengajaran dalam penyajian informasi yang akan diberikan terhadap siswa (Nababa, 2016).

Berdasarkan hasil observasi di SMP Negeri 2 Labuapi peneliti menemukan suatu permasalahan pada proses pembelajaran mata pelejaran IPA terpadu khususya mata pelajaran Fisika pada materi Suhu dan Kalor dimana terkendalanya dalam menyelesaikan pelajaran pada materi Suhu dan Kalor. Hal ini dapat dilihat dari kurangnya inisiatif siswa dalam mempersiapkan diri terhadap pelajaran yang akan dibahas. Siswa juga mengalami penurunan semangat belajar karena kurangnya inovasiinovasi pembelajaran yang diterapkan oleh guru mata pelajaran. Selain itu juga didapati masalah ketika proses pembelajaran media yang digunakan guru berupa Lembar Kerja Siswa (LKS) saja.

Oleh karena itu perlu adanya inovasi baru dalam proses pembelajaran untuk diterapkan dalam proses pembelajaran khususnya materi Suhu dan Kalor yaitu dengan mengunakan media pembelajaran berbantuan komputer. Peneliti menerapkan media pembelajaran ini diharapkan dapat digunakan sebagai alternatif dalam melaksanakan proses pembelajaran pada saat menurunya semangat belajar dan tentunya untuk membantu meningkatkan kualitas pembelajaran serta pemahaman siswa. Banyaknya media yang ada seperti Ms. Power Point, Adobe Flash, dan masih banyak lagi. Peneliti memilih dan menerapkan media pembelajaran dengan Sofwere GUI Matlab dalam pembelajaran IPA Terpadu khususnya pada materi Suhu dan Kalor. Pemilihan Matlab sebagai basis dikarenakan Matlab memiliki fasilitas pengembangan berupa GUI (Graphic User Interface) sehingga dapat memudahkan dalam perencanaan dan pembuatan media. GUI Designer mengandung menu, tombol, teks, grafik, dll dimana pengguna dapat mengubahnya secara interaktif dengan menggunakan mouse dan keyboard (Hunt, dkk, 2001). GUI Designer Matlab terdiri atas tiga elemen antaralain komponen, callbacks, dan figure. Matlab juga memiliki keunggulan dalam hal matematis, hal tersebut sangat sesuai untuk digunakan dalam pengembangan media pembelajaran (Sa'diyah dan Buditjahjanto, 2016).

Hal ini sesuai dengan hasil penelitian yang sudah dilakukan oleh Sa'diyah dan Budi tjahjanto (2016) tentang pengembangan GUI Designer Matlab sebagai media pembelajaran pada pokok bahasan teknik pengkodean sinyal di jurusan teknik elektro UNESA hasi uji coba pada 30 mahasiswa Jurusan Teknik Elektron memperoleh respon positif sebesar $79,81 \%$ untuk media dan $74,87 \%$ untuk materi ajar. Nilai $\mathrm{R}^{2}$ pada analisis regresi sebesar 0,863 (86,3\%), sehingga ketertarikan mahasiswa terhadap media berpengaruh signifikan terhadap hasil belajar.

Berdasarkan pertimbangan masalah yang dihadapi siswa pada proses pembelajaran IPA Terpadu khususnya mata pelajaran fisika SMP/MTs serta kelebihan yang ada pada GUI Matlab maka penulis tertarik untuk membuat softwere pembelajaran fisika yang lebih interaktif dan komunikatif tentang Suhu dan Kalor dengan menggunakan media berbasis GUI Matlab. Dengan harapan dapat membantu siswa dalam pemahaman materi sehingga kegiatan pembelajaran lebih efektif dan efisien.

Untuk dapat memenuhi semua harapan tersebut, dalam kesempatan ini Peneliti mengangkat penelitian yang berjudul "Pengembangan RUMFIS (Rumus Fisika) Berbasis Program Matlab pada Materi Suhu dan Kalor untuk meningkatkan motivasi belajar siswa SMP kelas VII".

\section{METODE PENELITIAN}

\section{Jenis Penelitian}

Jenis penelitian yang digunakan metode penelitian dan pengembangan atau dalam bahasa Inggrisnya Research and Development mengemukakan bahwa "Penelitian dan pengembangan adalah sebuah strategi atau metode penelitian yang cukup ampuh untuk memperbaiki praktik. Penelitian dan pengembangan adalah suatu proses atau langkah-lagkah untuk mengembangkan suatu produk baru atau menyempurnakan produk yang telah ada, yang dapat dipertangungjawabkan (Sukmadinata, 2016).

Desain penelitian ini menggunaka satu kelas sampel sebagai kelas uji coba (One Group Pre-Test and Post-test design). Teknik pengumpulan data pada penelitian ini adalah angket dan dokumentasi. Angket digunakan untuk mengumpulkan data tentang kelayakan media pembelajaran yang dibuat dan akan dijawab oleh responden yang terkait pembelajaran antara lain: ahli materi, ahli media dan siswa sebagai pengguna media pembelajaran RUMFIS berbasis program matlab. 
Yang menjadi objek penelitian pengembangan ini adalah RUMFIS berbasis Matlab pada materi Suhu dan Kalor dalam pelajaran IPA Fisika di kelas VII SMP Negeri 2 Labuapi.

\section{Langkah-Langkah Metode Penelitian dan Pengembangan}

Langkah-langkah Metode Penelitian Dan Pengembangan seperti pada gambar 1 .

Bagan di bawah ini, berdasarkan gambar 1 dapat diberikan penjelasannya

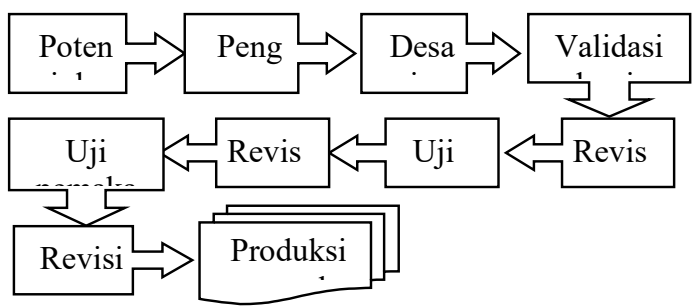

Gambar 1. Tampilan Langkah-langkah Metoe Reserch \& Development(Sugiyono, 2016).

Penelitian ini dilakukan sampai pada tahap uji coba produk karena keterbatasan waktu dan dana. Produk dikatakan valid apabila telah direvisi oleh ahli dan diuji keefektifannya oleh peneliti dengan adanya pengikatan motivasi belajar siswa.

\section{A. Potensi dan Masalah}

Penelitian dapat berangkat dari adanya potensi atau masalah. Potensi adalah segala sesuatu yang bila didayagunakan akan memilik nilai tambah. Sedangkan masalah adalah penyimpangan antara yang diharapkan dengan yang terjadi (Sugiyono, 2016).

Potensial dan masalah yang dikemukkan dalam penelitian harus ditunjukan dengan data empiris. Potensial yang ditemukan dalam penelitian ini adalah RUMFIS berbasis program Matlab dalam kegiatan pembelajaran. Masalah dalam penelitian ini adalah menurunya motivasi belajar siswa kalas VII SMP Negeri 2 Labuapi karena kurangnya media yang digunakan oleh guru mata pelajaran fisika.

\section{B. Mengumpulkan Informasi}

Setelah potensi dan masalah dapat ditunjukan secara factual dan uptode, maka selanjutnya perlu dikumpulkan berbagai informasi yang dapat digunakan sebagai bahan untuk perencanaan produk tertentu yang diharapkan dapat mengatasi masalah tersebut. Pada penelitian ini, peneliti akan menghasilkan dan mengembangkan produk berupa RUMFIS berbasis program Matlab. Berdasarkan hasil pengumpulan informasi yang telah dilakukan disekolah, ditemukan permasalahan adalah rendahnya motivasi belajar siswa. Salah satu pemicunya adalah kurangya media pembelajaran yang digunakan. Oleh karena itu, peneliti akan mengembangkan media pembelajaran berupa RUMFIS berbasis program Matlab yang menarik dan sangat praktis digunakan.

\section{Desain Produk}

Berdasarkan hasil analisis kebutuhan, langkah selanjutnya penelitian dan pengembangan membuat desain produk yang akan dikembangkan. Desain produk dalam penelitian ini diwujudkan dalam bentuk program Matlab, desain memuat rumus fisika, konversi suhu dan materi singkat yang mudah dipahami sehingga membangkitkan motivasi belajar siswa.

\section{Validasi Produk}

Validasi produk dapat dilakukan dengan cara menghadirkan beberapa pakar atau tenaga ahli yang sudah berpengalaman untuk menilai produk baru yang dirancang tersebut. Setiap pakar diminta untuk menilai desain tersebut, sehingga dapat diketahui kekurngan dan kelebihanya (Sugiyono, 2016).

Kegiatan validasi isi ini akan dilakukan oleh ahli media pembelajaran dan ahli materi fisika dengan cara mengisi instrument berupa angket dan memberi kritik dan saran terhadap produk pengembangan. Validasi isi dilakukan oleh para ahli bidang studi, dan pakar yang memiliki keahlian yang relevan dengan bidang kajiannya.

\section{E. Instrumen Penelitian}

Instrumen penelitian adalah suatu alat yang digunakan untuk mengukur fenomena yang terjadi pada penelitian yang dilakukan. Secara spesifik fenomena yang terjadi ini disebut variabel penelitian. Instrument yang digunakan dalam penelitian ini adalah sebagai berikut:

\section{Angket (kuisioner)}

Kuisioner merupakan teknik pengumpulan data yang dilakukan dengan cara memberi seperangkat pertanyaan atau pernyataan tertulis kepada responden untuk dijawabnya (Sugiyono, 2016).

Angket ini disusun berdasarkan kriteriakriteria yang terdapat dalam aplikasi yang sudah dibuat. Angket ini dibuat untuk ahli materi, ahli media, praktis dan siswa dengan angket yang berbeda sesuai dengan fungsi dan kepentingan masing-masing.

Angket validitas media pembelajaran memiliki gradulasi pertanyaan sangat positif sampai sangat negatif yang digunakan untuk mengukur indikator program yang berkaitan dengan kriteria pendidikan, tampilan dan kualitas teknis. 
Tabel 1. Kisi-Kisi Angket Validasi Ahli Media Pembelajaran RUMFIS berbasis Program Matlab.

\begin{tabular}{|c|c|c|c|c|c|}
\hline \multirow{2}{*}{ No } & \multirow{2}{*}{ Aspek } & \multirow{2}{*}{ Indikator } & \multicolumn{2}{|c|}{ Responden } & \multirow{2}{*}{$\begin{array}{l}\text { Nomor } \\
\text { Item }\end{array}$} \\
\hline & & & $\begin{array}{c}\text { Ahli } \\
\text { Materi }\end{array}$ & $\begin{array}{c}\text { Ahli } \\
\text { Media }\end{array}$ & \\
\hline \multirow[t]{3}{*}{1} & \multirow{3}{*}{$\begin{array}{l}\text { Kebenaran } \\
\text { konsep dan } \\
\text { materi }\end{array}$} & $\begin{array}{l}\text { Kesesuaian penyusunan materi dengan } \\
\text { kompetensi dasar }\end{array}$ & & & 1 \\
\hline & & $\begin{array}{l}\text { Kesesuaian penyusunan materi dalam GUI } \\
\text { Matlab dengan materi suhu dan kalor }\end{array}$ & & & 2 \\
\hline & & $\begin{array}{l}\text { Kesesuaian materi dengan indikator } \\
\text { pembelajaran }\end{array}$ & & & 3 \\
\hline \multirow[t]{4}{*}{2} & \multirow[t]{4}{*}{ Pencakupan isi } & $\begin{array}{l}\text { Uraian materi singkat beserta rumus- } \\
\text { rumusnya mempermudah pemahaman siswa } \\
\text { terhadap materi suhu dan kalor. }\end{array}$ & & & 4 \\
\hline & & $\begin{array}{l}\text { Pengetahuan tambahan siswa tentang materi } \\
\text { suhu dan kalor dalam GUI Matlab }\end{array}$ & & & 5 \\
\hline & & $\begin{array}{l}\text { Ketertarikan terhadap bentuk evaluasi } \\
\text { pembelajaran fisika }\end{array}$ & & & $6 \operatorname{dan} 7$ \\
\hline & & Penjabaran evaliasi siswa & & & 8 \\
\hline 3 & $\begin{array}{l}\text { Aspek } \\
\text { karakter }\end{array}$ & $\begin{array}{l}\text { Kegiatan dalam menjalankan dan } \\
\text { menggunakan program GUI Matlab dapat } \\
\text { membentuk karakter mandiri, tanggung } \\
\text { jawab, kretif dan teliti }\end{array}$ & & & 9 \\
\hline \multirow[t]{2}{*}{4} & \multirow[t]{2}{*}{ Penulisan } & Ukuran tulisan GUI Matlab yang dibuat & & & 1 \\
\hline & & Ketetapan bahasa yang sesuai & & & 2 dan 3 \\
\hline \multirow[t]{3}{*}{5} & \multirow{3}{*}{$\begin{array}{l}\text { Tampilan fisik } \\
\text { GUI Matlab } \\
\text { berbentuk } \\
\text { buku saku }\end{array}$} & $\begin{array}{l}\text { Des ain cover RUMFIS berbasi program GUI } \\
\text { Matlab }\end{array}$ & & & 4 dan 5 \\
\hline & & Perpaduan warna padaprogram GUI Matlab & & & 6 \\
\hline & & $\begin{array}{l}\text { Kesesuaian perpaduan antara gambar dengan } \\
\text { materi }\end{array}$ & & & 7 \\
\hline 6 & $\begin{array}{l}\text { Kalimat dan } \\
\text { tingkat } \\
\text { keterbacaan }\end{array}$ & $\begin{array}{l}\text { Kejelasan kalimat yang digunakan dalam } \\
\text { GUI Matlab. }\end{array}$ & & & $8 \operatorname{dan} 9$ \\
\hline \multirow[t]{2}{*}{7} & \multirow{2}{*}{$\begin{array}{l}\text { Tingkat } \\
\text { penggunaan } \\
\text { GUI Matlab }\end{array}$} & Memudahkan proses belajar & & & 1,2 dan 3 \\
\hline & & $\begin{array}{l}\text { Kepraktisan pembuatan dan penggunaan GUI } \\
\text { Matlab }\end{array}$ & & & $\begin{array}{l}4,5,6,7,8 \\
\operatorname{dan} 9\end{array}$ \\
\hline
\end{tabular}

Tabel 2. Kisi-kisi Angket Motivasi Belajar Siswa terhadap Media Pembelajaran RUMFIS berbasis Program Matlab

\begin{tabular}{|c|c|c|c|}
\hline No & Indikator & Item & Nomor \\
\hline 1 & Perhatian & Siswa mendengarkan arahan guru & $1,2,3$ dan 4 \\
\hline \multirow[t]{2}{*}{2} & \multirow[t]{2}{*}{ Relevansi } & $\begin{array}{l}\text { Siswa memperhatikan setiap kesalahan dalam } \\
\text { RUMFIS berbasis program matlab }\end{array}$ & 26,27 dan 28 \\
\hline & & $\begin{array}{l}\text { Siswa memperhatikankesesuaian materi yang di } \\
\text { GUI Matlab dengan yang guru jelaskan }\end{array}$ & 29 dan 30 \\
\hline \multirow[t]{3}{*}{3} & \multirow[t]{3}{*}{$\begin{array}{l}\text { Kepercayaan } \\
\text { dir }\end{array}$} & $\begin{array}{l}\text { Mengerjakan evaluasi yang diberikan oleh guru } \\
\text { yang ada dalam RUMFIS berbasis program } \\
\text { Matlab }\end{array}$ & $5,6,7$ dan 8 \\
\hline & & $\begin{array}{l}\text { Siswa merasa berkompeten terhadap maten } \\
\text { yang dipelajan }\end{array}$ & 19,20 dan 21 \\
\hline & & $\begin{array}{l}\text { Siswa dapat berinteraksi dengan guru dan } \\
\text { lingkungan sosial }\end{array}$ & $22,23,24$ dan 25 \\
\hline \multirow[t]{2}{*}{4} & \multirow[t]{2}{*}{ Kepuasan } & $\begin{array}{l}\text { Siswa dapat mengetahui penerapan mater } \\
\text { pembelajaran dalam kehidupan sehari-han }\end{array}$ & $\begin{array}{l}9,10,11,12,13,14 \\
\text { dan } 15\end{array}$ \\
\hline & & $\begin{array}{l}\text { Siswa merasa puas setelah berhasil mencapai } \\
\text { tujuan pembelajaran }\end{array}$ & 16,17 dan18 \\
\hline
\end{tabular}

(Uno. 2016) 
Angket motivasi belajar digunakan untuk mengetahui pengaruh penggunaan program GUI Matlab terhadap motivasi belajar siswa. Di bawah ini merupakan tabel kisi-kisi angket motivasi belajar siswa.

Skala pengukuran yang digunakan dalam angket validasi produk dan motivasi belajar siswa adalah skala likert yang memiliki gradulasi dari sangat positif sampai sangat negati. Teknik skorsing dalam skala likert adalah sebagai berikut:

Tabel 3. Pemberian Skor Skala Likert

\begin{tabular}{|l|l|l|}
\hline \multirow{2}{*}{$\begin{array}{c}\text { Pilihan } \\
\text { Jawaban }\end{array}$} & \multicolumn{2}{|c|}{ Pernyataan/Pertanyaan } \\
\cline { 2 - 3 } & \multicolumn{1}{|c|}{ Negatif } & Positif \\
\hline $\begin{array}{l}\text { Sangat setuju } \\
\text { (sangat positif) }\end{array}$ & Skor 1 & Skor 5 \\
\hline Setuju (positif) & Skor 2 & Skor 4 \\
\hline $\begin{array}{l}\text { Kurang setuju } \\
\text { (negatif) }\end{array}$ & Skor 3 & Skor 3 \\
\hline $\begin{array}{l}\text { Tidak setuju } \\
\text { (sangat } \\
\text { negatif) }\end{array}$ & Skor 4 & Skor 2 \\
\hline $\begin{array}{l}\text { Sangat tidak } \\
\text { setuju (sangat } \\
\text { negatif) }\end{array}$ & Skor 5 & Skor 1 \\
\hline
\end{tabular}

(Azwar, 2015)

\section{F. Teknik Analisis Data}

Teknik analisis data angket validasi produk Teknik analisis data pada penelitian ini bertujuan untuk mendapatkan perangkat pembelajaran yang berkualitas. Adapun langkahlangkah yang digunakan dalam memenuhi kriteria kualitas produk yang dikembangkan adalah sebagai berikut:

a. Data berupa skor ahli/pratisi yang diperoleh melalui lembar validasi yang dijumlahkan.

b. Menghitung skor rata-rata dengan menggunakan rumus

c. Total skor aktual yang diperoleh kemudian dikonversikan menjadi data kualitatif skala lima seperti pada tabel berikut:

Tabel 4. Konversi Data Kuantitatif Ke Kualitatif Dengan Skala Lima

\begin{tabular}{|c|c|c|}
\hline Interval & Kriteria & Skor \\
\hline$(\mathrm{M}+1,50 \mathrm{~s})<\mathrm{X}$ & Sangat baik & A \\
\hline$(\mathrm{M}+0,50 \mathrm{~s})<\mathrm{X} \leq(\mathrm{M}+1,50 \mathrm{~s})$ & Baik & B \\
\hline$(\mathrm{M}-0,50 \mathrm{~s})<\mathrm{X} \leq(\mathrm{M}+0,50 \mathrm{~s})$ & Cukup baik & $\mathrm{C}$ \\
\hline$(\mathrm{M}-1,50 \mathrm{~s})<\mathrm{X} \leq(\mathrm{M}-0,50 \mathrm{~s})$ & Kurang baik & $\mathrm{D}$ \\
\hline $\mathrm{X} \leq(\mathrm{M}-1,50 \mathrm{~s})$ & Tidak baik & $\mathrm{E}$ \\
\hline
\end{tabular}

(Azwar, 2015)

Keterangan:

$X=$ Total skor responden

$M=$ Mean ideal, $1 / 2$ (skor maksimal ideal+skor minimal ideal) $\mathrm{s}=$ Simpangan baku ideal, $1 / 6$ (skor maksimal ideal-skor minimal ideal)

\section{Teknik analisis data angket motivasi siswa}

Analisis data dilakukan setelah proses pengumpulan data, dimana penelitian ini lebih menitikberatkan pada pengembangan RUMFIS berbasis program Matlab pada materi suhu dan kalor kelas VII. Angket yang digunakan harus dilakukan uji validitas dan uji reabilitas.

a. Uji Validitas

Untuk menghitung banyaknya pertanyaan yang valid atau tidak dapat dihitung nilai validitas dengan rumus Pearson Product Moment adalah:

$$
r_{x y}=\frac{n \sum X_{i} Y_{i}-\left(\sum X_{i}\right) \cdot\left(\sum Y_{i}\right)}{\left.\sqrt{\left\{n \sum X_{i}{ }^{2}-\left(\sum X_{i}\right)^{2}\right\}}\right\}\left\{n \cdot \sum Y_{i}{ }^{2}-\left(\sum Y_{i}\right)^{2}\right\}}
$$

Keterangan:

$r_{\text {hitung }}=$ Koefisien korelasi

$\mathrm{X}_{\mathrm{i}}=$ Jumlah skor item

$\mathrm{Y}_{\mathrm{i}}=$ Jumah skor total (seluruh item)

$\mathrm{n}=$ Jumlah responden

(Riduwan, 2014)

b. Uji Reliabilitas

Uji reabilitas dilakukan untuk mengetahui reabilitas angket, (instrumen) dengan menggunakan rumus Alpha crobanch

$$
r_{11}=\left(\frac{k}{k-1}\right)\left(1-\frac{\sum S_{i}}{S_{t}}\right)
$$

Keterangan:

$r_{11}=$ Nilai reliabilitas

$\sum S_{i}=$ Jumlah varians skor tiap-tiap item

$S_{t}=$ Varians total

$k=$ Jumlah item

Selain itu perlu dicari nilai varians untuk menentukan reliabilitas angket motivasi belajar siswa menggunakan rumus sebagai berikut:

$$
S_{i}=\frac{\sum X_{i}{ }^{2}-\frac{\left(\sum X_{i}\right)^{2}}{N}}{N}
$$

Keterangan:

$S_{i} \quad=$ Varians skor tiap-tiap item

$\sum X_{i}{ }^{2}=$ Jumlah kuadrat item $\mathrm{Xi}$

$\left(\sum X_{i}\right)^{2}=$ Jumlah item Xi dikuadratkan

$$
\mathrm{N}=\text { Jumlah responden }
$$

Nilai korelasi yang diperoleh dikonsultasikan ke tabel Product Moment dengan taraf $a=0,05$ atau $a=0,01$. Jika harga rhitung $\mathrm{r}_{\text {tabel }}$ maka reliabel dan harga $r_{\text {hitung }}<r_{\text {tabel }}$ berarti tidak reliabel (Riduwan, 2014). 
c. Motivasi belajar siswa

Untuk menghitung angket tingkat motivasi siswa digunkan persamaan berikut:

Tabel 3.5 Penilaian Skala 1-5 Motivasi Belajar Siswa

\begin{tabular}{|c|c|}
\hline Interval & Skor \\
\hline$(\mathrm{M}+1,50 \mathrm{~s})<\mathrm{X}$ & A \\
\hline$(\mathrm{M}+0,50 \mathrm{~s})<\mathrm{X} \leq(\mathrm{M}+1,50 \mathrm{~s})$ & B \\
\hline$(\mathrm{M}-0,50 \mathrm{~s})<\mathrm{X} \leq(\mathrm{M}+0,50 \mathrm{~s})$ & $\mathrm{C}$ \\
\hline$(\mathrm{M}-1,50 \mathrm{~s})<\mathrm{X} \leq(\mathrm{M}-0,50 \mathrm{~s})$ & $\mathrm{D}$ \\
\hline $\mathrm{X} \leq(\mathrm{M}-1,50 \mathrm{~s})$ & E \\
\hline
\end{tabular}

(Azwar, 2015)

Keterangan:

$\mathrm{X}=$ Total skor responden

$M=$ Mean ideal, $1 / 2$ (skor maksimal ideal+skor minimal ideal)

$\mathrm{s}=$ Simpangan baku ideal, 1/6 (skor maksimal ideal-skor minimal ideal)

Data motivasi belajar siswa diolah setiap pertanyaan kemudian diolah berdasarkan indikator. Data perindikator setelah diolah maka motivasi belajar siswa dapat diketahui. Data motivasi belajar siswa dihitung dengan persamaan berikut:

$$
\%=\left(\frac{n}{N}\right) \times 100 \%
$$

Keterangan:

$n$ = skor yang diperoleh

$N=$ jumlah seluruh skor maksimal

Menghitung besarnya peningkatan motivasi belajar siswa dengan menggunakan rumus Hake:

$$
\text { gain }=\frac{S_{\text {post }} S_{\text {pre }}}{100-S_{\text {pre }}}
$$

Keterangan:

g(gain) = gain

Spre = skor awal

$S_{\text {post }}=$ skor akhir

Data hasil perhitungan angket motivasi sebelum dan sesudah siswa kemudian akan diiterpretasikan dengan menggunakan gain standar sebagai berikut:

Tabel 5. Nilai Indeks Gain Standar

\begin{tabular}{|l|l|}
\hline Nilai gain standar & $\begin{array}{l}\text { Keteranga } \\
\mathrm{n}\end{array}$ \\
\hline$\geq 0,7$ & Tinggi \\
\hline $0,7 \geq g \geq 0,3$ & Sedang \\
\hline$\leq 0,3$ & Rendah \\
\hline
\end{tabular}

(Hake, 1998)

Apabila media pembelajaran dapat meningkatkan motivasi belajar siswa, maka media pembelajaran dikatakan telah teruji keefektifannya.

HASIL DAN PEMBAHASAN

Hasil Penelitian

A. Metode Penelitian Tahap I

Potensi dan Masalah

Potensi yang ditemukan dalam penelitian ini adalah RUMFIS berbasis program matlab dan pembelajaran. Masalah dalam penelitian ini adalah kurangnya motivasi belajar siswa kelas VII SMP Negeri 2 Labuapi terhadap mata pelajaran IPA Fisika.

\section{Mengumpulkan Informasi}

Pengumpulan informasi dilakukan dengan observasi peneliti, di SMP Negeri 2 Labuapi ditemukan permasalahan terkait dengan pembelajaran fisika. Salah satu permasalahannya adalah rendahnya motivasi belajar siswa. Salah satu pemicunya adalah kurangnya media pembelajaran yang digunakan sehingga siswa sedikit sekali yang tertarik pada pelajaran fisika, selain dari itu adanya anggapan bahwa pembelajaran fisika banyak sekali rumus-rumus dan sukar dipahami. Sikap mereka terhadap fisika bisa dilihat dari menurunnya motivasi belajar siswa serta kurang adanya perhatian sampai penolakan mendalam. Dalam hal ini, guru selaku tenaga pengajar hendaknya bisa lebih kreatif dalam mengelola atau mendesain kegiatan pembelajaran agar pembelajaran menjadi lebih menyenangkan. Jika para siswa senang belajar fisika, tentu mereka bisa menjadi lebih aktif. Keaktifan yang dimaksud disini tentu saja keaktifan yang mampu melibatkan mental dan emosionalnya.

\section{Desain Produk}

Berdasarkan kondisi yang telah ada di sekolah, dapat diketahui bahwa dalam pelaksanaan pembelajaran RUMFIS berbasis program matlab sangat dibutuhkan sebagai media evaluasi pembelajaran siswa. Karena evaluasi yang ada di buku pembelajaran di sekolah belum bisa meningkatkan motivasi belajar siswa. Bentuk evaluasi yang ada di buku pembelajaran kurang menarik dan membosankan karena dituntut untuk fokus menjawab yang ada sedangkan di RUMFIS berbasis program matlab selain fokus menjawab soal, siswa juga bisa belajar menggunakan teknologi dan gambar serta warna yang ditampilkan RUMFIS sangat menarik. Dengan demikian, maka diperlukan media berupa evaluasi belajar bagi siswa yang mampu meningkatkan motivasi belajar.

Media pembelajaran RUMFIS berbasis program matlab yang dihasilkan yaitu terdiri dari rumus, materi singkat, dan soal evaluasi yang dibuat semenarik mungkin dengan memadukan gambar - gambar serta warna - warna yang 
indah. RUMFIS berbasis program matlab yang dibuat memiliki jenis dan ukuran tulisan yang mudah dibaca. Desain produk dikerjakan dengan menggunakan program GUI matlab sedangkan untuk desain tampilan loading dan home menggunakan photohsop.

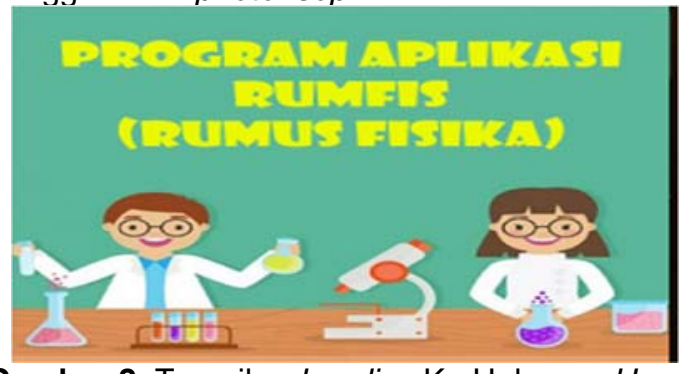

Gambar 2. Tampilan Laoding Ke Halaman Home

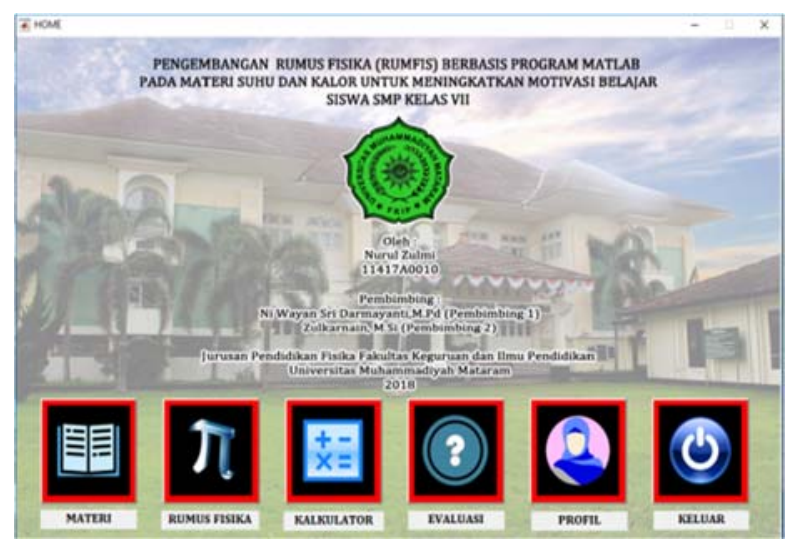

Gambar 3. Tampilan Halaman Home

\section{Hasil Validasi Ahli}

Kegiatan validasi media pembelajaran RUMFIS berbasis program matlab dilakukan para ahli dengan mengisi angket yang berisi 29 pertanyaan yang terdiri dari kriteria pendidikan, kriteria tampilan, dan kriteria teknis. Media pembelajaran fisika berbantuan RUMFIS berbasis program matlab divalidasi oleh 4 ahli yang dianggap respresentasi dan berpengalaman mengajar materi IPA Fisika. Angket diisi oleh ahli yang terdiri 3 orang dosen dan 1 guru SMP Negeri 2 Labuapi. Hasil validasi media pembelajaran fisika berbantuan RUMFIS berbasis program matlab adalah sebagai berikut :

\section{Ahli I}

Sesuai dengan hasil pengisian angket dari Baiq Desi Milandari, M.Pd, selaku ahli I, ratarata nilai yang diberikan pada kriteria pendidikan, tampilan dan teknis berada pada skala 4 (setuju). Sementara pengisian angket pada kriteria pendidikan berada pada skala 5 ( sangat setuju) pada item soal nomor 9. Dan pengolahan data dari pengisian angket oleh ahli I berada pada interval sangat baik ditebalkan untuk kriteria pendidikan, sangat baik untuk kriteria tampilan dan untuk kriteria teknik berada pada baik dan rekomendasi dari ahli I merekomendasikan perbaikan pada kerapian gambar dan harus proposional. Dan dapat disimpulkan penilain dari ahli I bahwa media dapat digunakan tapi dengan direvisi font dan tampilan diperjelas.

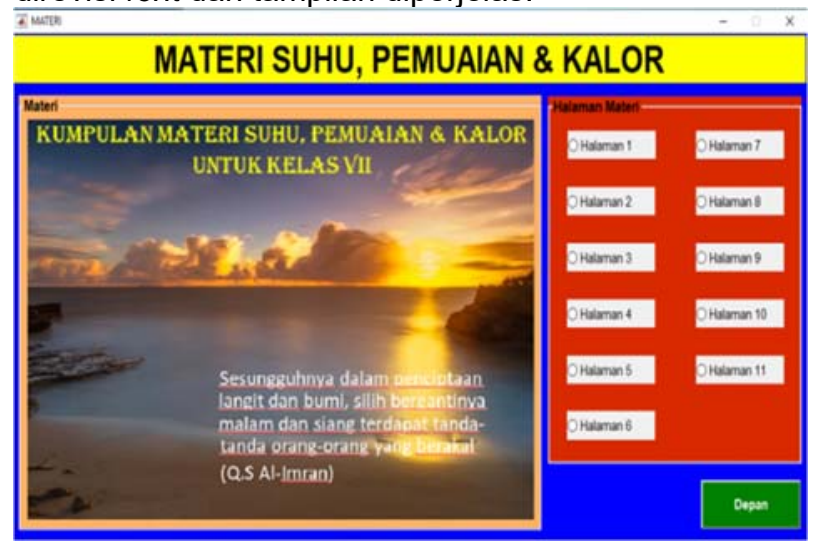

Gambar 4.3 Revisi Tampilan gambar

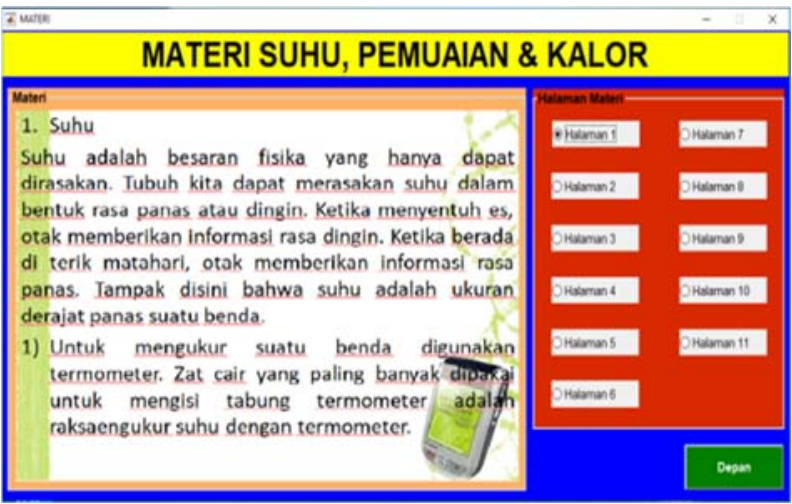

Gambar 5. Font Tulisan dan Mudah Dibaca

\section{Ahli II}

Pengisian angket dari Islahudin, M.Pfis selaku ahli II diperoleh pengisian angket tertinggi berada di skala 5 yaitu sangat setuju pada kriteria pendidikan yang terdapat pada item nomor 2,6 , 7, 8 dan 9 dengan pernyataan evaluasi yang ada pada RUMFIS berbeda sehingga menarik bagi siswa. Sedangkan pengisian angket terendah berada pada skala 4 (setuju) terdapat pada kriteria pendidikan yaitu item nomor $1,3,4,5$ dan 10 yaitu dengan pernyataan hubungan antara materi pada media pembelajaran dalam media pembelajaran fisika berbantuan RUMFIS berbasis program matlab dengan kehidupan sehari-hari mampu meningkatkan pendidikan karakter. Pengolahan datanya menggunakan interval, diperoleh hasil dari pengisian angket ahli II untuk kualitas pendididkan sangat baik, kualitas tampilan baik dan kualitas teknik sangat baik. Denga demikaian pengisian angket dari ahli II disimpulkan bahwa RUMFIS berbasis program matlab untuk digunakan dan dinyatakan dengan 
revisi penambahan kunci jawaban pada bagian evaluasi.

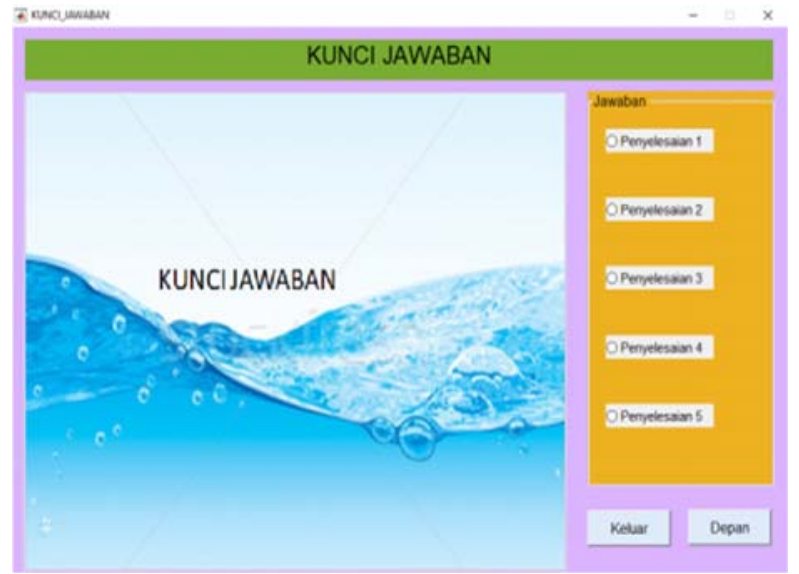

Gambar 6. Revisi Penambahan

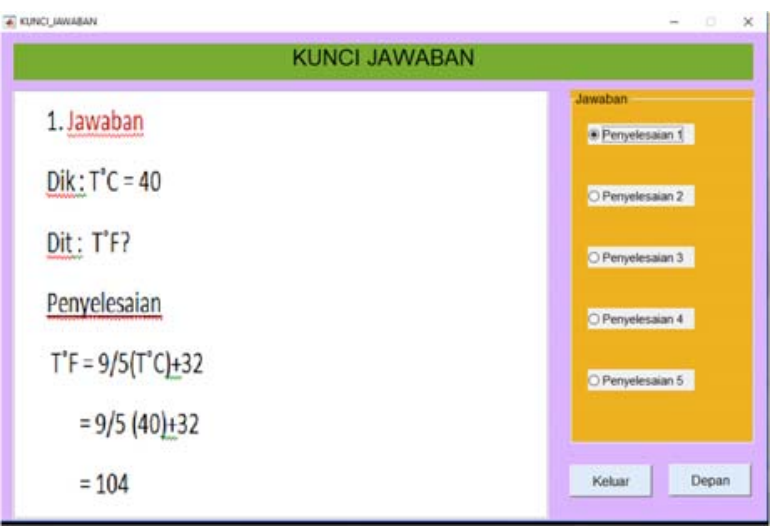

Gambar 7. Tampilan Kunci Jawaban Kunci JawabanNomor 1

\section{Ahli III}

Pengisian angket dari Linda Sekar Utami, M.Pfis selaku ahli III diperoleh pengisian angket tertinggi berada di kriteria tampilan pada item nomor 2, 3, 7 dan 8 berada pada skala 5 yaitu sangat setuju dan kriteria pendidikan dari nomor item 1 sampai dengan 10 berada pada skala 4, yaitu setuju dan kriteria tehnik kecuali nomor item 7 semuanya berada pada skala 4, yaitu setuju. Sedangkan pengisian angket terendah berada pada skala 3, yaitu kurang setuju. Dari pengolahan datanya menggunkan interval, diperoleh hasil pengisian angket ahli III untuk kualitas pendidikan baik, kualitas tampilan baik dan kualitas teknik baik. Ahli III merekomendasikan perbaikan revisi pada bagian latar belakang dan evaluasi agar lebih jelas.

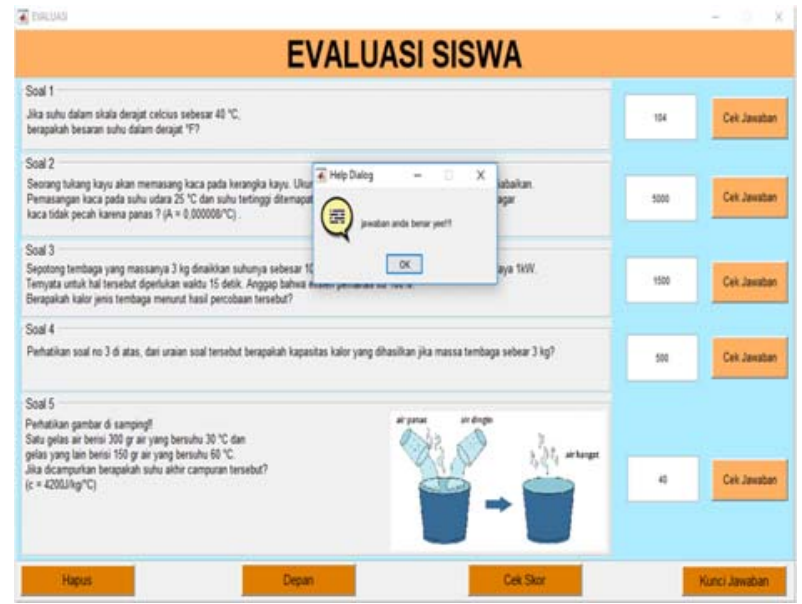

Gambar 8. Tampilan Halaman Evaluasi

\section{Praktisi}

Hasil pengisian angket dari Andriana Puji Sunarti, S.Pd selaku praktisi bahwa pengisian angket tertinggi rata-rata berada pada skala (sangat setuju) terdapat pada kriteria pendidikan, tampilan dan teknis. Sedangkan pengisian angket terendah berada pada skala 4 (setuju). Dari hasil pengisian angket praktisi untuk kualitas pendidikan, kualitas tampilan dan kualitas teknis diperoleh hasil pengolahan datanya menggunakan interval berada pada kriteria sangat baik dari ke tiga kriteria tersebut dimana berdasarkan praktisi tidak ada revisi pada produk dan menyarankan agar media RUMFIS berbasis program matlab bisa diterapkan pada mata pelajaran yang lain.

Berikut bagian rumus dan konversi suhu pada media RUMFIS berbasis program matlab adalah:

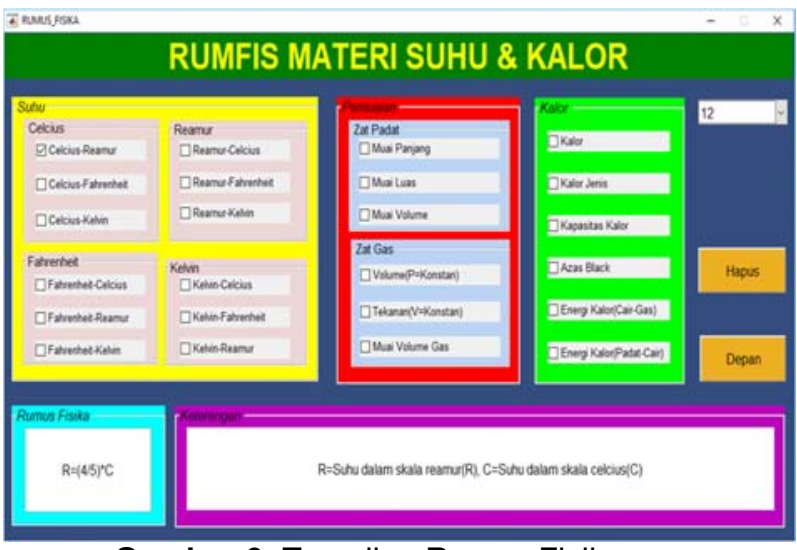

Gambar 9. Tampilan Rumus Fisika 


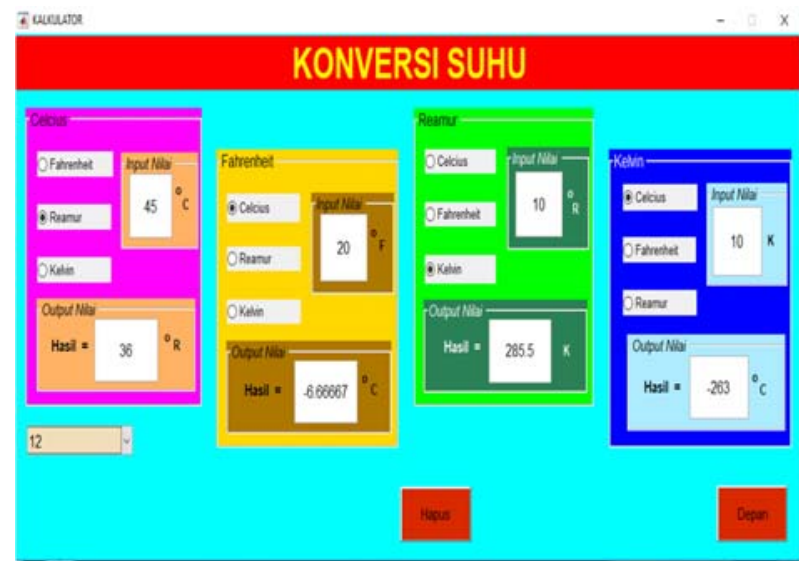

Gambar 10. Tampilan Konversi Suhu

\section{Revisi produk}

Hasil validasi produk yang telah dilakukan menunjukkan bahwa RUMFIS berbasis program matlab harus dilakukan revisi pada bagian tertentu, yaitu latar belakang pada materi, kejelasan tampilan, dan penambahan kunci jawaban.

\section{B. Metode Penelitian Tahap II Hasil Uji Validitas Angket}

Media pembelajaran RUMFIS berbasis program matlab selanjutnya diterapkan untuk meningkatkan motivasi belajar siswa kelas VII SMP Negeri 2 Labuapi. Peningkatan motivasi belajar siswa dapat diukur dengan memberikan angket motivasi belajar kepada siswa. Ada beberapa bentuk aspek motivasi belajar yang ingin diketahui dalam penelitian ini antara lain, motivasi berupa perhatian, relevansi, kepercayaan diri, dan kepuasan.

Uji validitas dilakukan pada pernyataan angket dengan menggunakan persamaan korelasi product moment. Hasil uji validitas angket motivasi belajar adalah sebagai berikut:

Tabel 6. Hasil Perhitungan Validitas Pernyataan

\begin{tabular}{|l|l|l|}
\multicolumn{3}{c}{ Angket } \\
\hline $\begin{array}{l}\text { Jumlah } \\
\text { Pernyataan }\end{array}$ & Valid & Tidak Valid \\
\hline 30 & 16 & 14 \\
\hline
\end{tabular}

\section{Hasil Uji Reliabilitas Angket}

Pernyataan pada angket diuji

keajengan/keandalannya dengan menggunakan persamaan alpha cronbach. Hasil uji reliabilitas pada pernyataan dapat dilihat pada tabel berikut ini:

Tabel 7. Hasil Perhitungan Reliabilitas Pernyataan Angket

\begin{tabular}{|l|l|l|}
\hline $\begin{array}{l}\text { Jumlah } \\
\text { Pernyataan }\end{array}$ & Reliabel & Tidak Reliabel \\
\hline 30 & 16 & 14 \\
\hline
\end{tabular}

\section{Hasil Uji Coba}

Uji coba yang digunakan yakni di kelas VII SMP Negeri 2 Labuapi dengan mengunakan angket motivasi yang sudah valid kemudian diberikan kepada siswa sebelum pembelajaran dimulai kegiatan pengisian angket dapat dilakukan selama 15 menit pada awal pertemuan sebelum kegiatan pembelajaran dan di akhir pembelajaran materi Suhu dan Kalor.

Perhitungan motivasi belajar siswa dilakukan pada setiap bentuk aspek atau indikator motivasi. Hasil angket motivasi kemudian diolah dengan menggunakan langkah-langkah yang dilakukan. Berdasarkan hasil perhitungan dalam penelitian yang dilakukan, maka dapat dilihat peningkatan motivasi belajar pada siswa.

Persentase hasil perhitungan motivasi siswa tiap indikator sebelum menggunakan RUMFIS berbasis program matlab dapat dilihat pada grafik berikut ini:

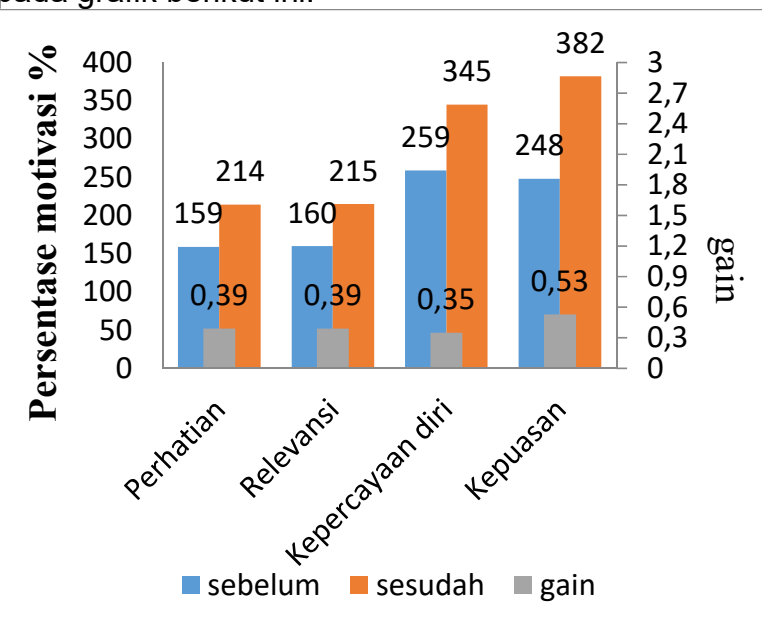

Gambar 11. Persentase Motivasi Siswa Setiap Indikator Sebelum dan Sesudah Penggunaan RUMFIS berbasis program matlab

Hasil perhitungan motivasi belajar siswa secara jelas dapat dilihat pada lampiran 13 halaman 154. Peningkatan motivasi belajar siswa juga harus dilihat secara klasikal. Dari hasil perhitungan dengan konversi data, diperoleh motivasi peserta didik seperti pada kedua tabel berikut ini.

Table 8. Kelompok Tingkat Motivasi Siswa Menggunakan Media Konvensional

\begin{tabular}{|c|c|c|c|}
\hline No & Interval & Jumlah Siswa & $\begin{array}{c}\text { Tingkat Motivasi } \\
\text { Belajar }\end{array}$ \\
\hline 1 & $64,005<\mathrm{X}$ & 0 & Sangat baik \\
\hline 2 & $53,335<\mathrm{X} \leq 64,005$ & 0 & Baik \\
\hline 3 & $42,665<\mathrm{X} \leq 53,335$ & 10 & Cukup baik \\
\hline 4 & $31,995<\mathrm{X} \leq 42,665$ & 9 & Kurang baik \\
\hline 5 & $\mathrm{X} \leq 31,995$ & 1 & Tidak baik \\
\hline
\end{tabular}


Taabel 9. Kelompok Tingkat Motivasi Siswa Menggunkan RUMFIS Berbasis Program Matlab

\begin{tabular}{|c|c|c|c|}
\hline No & Interval & Jumlah Siswa & $\begin{array}{c}\text { Tingkat Motivasi } \\
\text { Belajar }\end{array}$ \\
\hline 1 & $64,005<\mathrm{X}$ & 3 & Sangat baik \\
\hline 2 & $53,335<\mathrm{X} \leq 64,005$ & 16 & Baik \\
\hline 3 & $42,665<\mathrm{X} \leq 53,335$ & 1 & Cukup baik \\
\hline 4 & $31,995<\mathrm{X} \leq 42,665$ & 0 & Kurang baik \\
\hline 5 & $\mathrm{X} \leq 31,995$ & 0 & Tidak baik \\
\hline
\end{tabular}

Secara klasikal, motivasi belajar siswa mengalami peningkatan. Peningkatan motivasi secara jelas dibuktikan bahwa persentase motivasi peserta didik menggunakan media konvensional adalah sebanyak $51 \%$. Setelah penggunaan RUMFIS berbasis program matlab persentase motivasi belajar siswa mengalami peningkatan menjadi $72 \%$. Besar peningkatan motivasi dengan normalisasi nilai gain adalah 0,43 dimana peningkatan motivasi belajar siswa berada dalam kriteria sedang. Persentase peningkatan motivasi belajar siswa dapat dilihat pada grafik berikut ini:

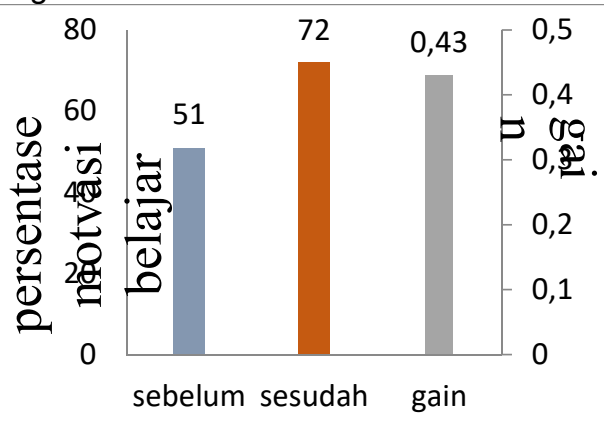

Gambar 12. Persentase Peningkatan Motivasi Belajar Secara Klasikal

\section{Pembahasan}

\section{A. Metode Penelitian Tahap I Potensi dan Masalah}

Berdasarkan hasil observasi peneliti, di SMP Negeri 2 Labuapi dalam penelitian ini rumus fisika yang mudah dipelajari lengkap dengan materi memanfaatkan perkembangn teknologi. Masalah yang utama adalah menurunnya motivasi belajar siswa ditunjukkan dengan kurangnya perhatian siswa dalam penjelasan guru, malasnya siswa mencatat materi pembelajaran, kurangnya kemauan belajar siswa dan kurangnya motivasi belajar siswa. Salah satu penyebabnya adalah kurangnya media yang digunakan guru pada saat mengajar.

Dalam menciptakan kondisi belajar siswa aktif tersebut, diperlukan suatu media pembelajaran. Media pembelajaran adalah setiap alat pembelajaran yang cocok untuk dapat memberikan pembelajaran menjadi lebih menarik, lebih jelas dan lebih mudah dipahami. Dalam fisika, alat yang biasa digunakan adalah aplikasi (program), slide, film, gambar, poster, Lembar Kerja Siswa (LKS), kaset pita suara, daftar dinding dan lain-lain. RUMFIS berbasis program matlab ini berisi kegiatan-kegiatan terprogram yang langsung dilengkapi dengan gambar cara kerja sehingga mampu memberikan kesan mudah bagi siswa. RUMFIS berbasis program matlab ini juga dilengkapi dengan soal-soal yang disajikan dalam bentuk program yang menarik.

\section{Desain Awal Produk}

Kondisi pada potensi dan masalah yang ada mendorong peneliti untuk mengembangkan RUMFIS berbasis program matlab untuk membantu proses pebelajaran. RUMFIS berbasis program matlab memiliki kelebihan antara lain dapat mningkatkan motivasi belajaar siswa. Selain itu juga RUMFIS berbasis program matlab ini telah dibuat sebanyak 4 figur utama dengan setiap figur terdiri dari materi, rumus, konversi suhu dan evaluasi yang dipisah dimana setiap figur dipadukan beberapa warna beserta background yang menarik. Sehingga RUMFIS berbasis program matlab yang telah dibagikan dan digunakan oleh siswa-siswi SMP Negeri 2 Labuapi menarik motivasi belajar siswa.

Media pembelajaran fisika berbantuan RUMFIS berbasis program matlab yang telah dihasilkan yaitu terdiri dari materi singkat, rumus fisika, konversi suhu dan evaluasi. RUMFIS berbasis program matlab yang dibuat memiliki jenis dan ukuran tulisan yang mudah dibaca. Desain tampilan loading dan home menggunakan photoshop sedangkan produk dikerjakan dengan menggunakan program matlab versi 8.02015 kemudian dikonversi dari M-file menjadi EXE-file dengan menggunakan program matlab itu sendiri agar mudah di copi dan digunakan.

Hasil Validasi Ahli

Media pembelajaran yang telah didesain divalidasi oleh ahli sebelum diuji coba. Validasi RUMFIS berbasis program matlab dilakukan oleh 4 ahli.

Hasil validasi dari ahli praktisi mengatakan tidak ada revisi terhadap produk karena sudah dikatakan layak untuk digunakan pada produk dan menyarankan agar media RUMFIS berbasis program matlab bisa diterapkan pada mata pelajaran yang lain. Hasil yang berbeda diperoleh dari ahli I, II dan III merekomendasikan perbaikkan mengenai gambar latar, ukuran, penambahan figur kunci jawaban dan evaluasi. Hasil validasi ahli menunjukkan bahwa media pembelajaran RUMFIS berbasis program matlab layak digunakan dalam pembelajaran setelah melakukan revisi.

\section{Revisi Produk}

Produk RUMFIS berbasis program matlab yang telah divalidasi pada bagian gambar latar, 
ukuran, penambahan figur kunci jawaban dan evaluasi , desain harus lebih menarik, dan warna tulisannya harus cerah agar bisa dibaca.

Hasil validasi ahli I, II, dan III mengatakan ada revisi terhadap produk. Hasil yang berbeda diperoleh dari praktisi. Praktisi merekomendasikan revisi agar media RUMFIS bisa digunakan pada mata pelajaran yang lain selain fisika. Hasil validasi ahli menunjukan bahwa media pembelajaran RUMFIS berbasis program matlab layak digunakan dalam pembelajaran setelah melakukan revisi. Untuk lebih jelas perhatikan tabel ini:

Table 10. Hasil Validasi Kriteria Pendidikan

\begin{tabular}{|c|l|c|c|c|c|c|c|c|c|c|c|c|c|}
\hline No & \multicolumn{1}{|c|}{ Nama ahi } & 1 & 2 & 3 & 4 & 5 & 6 & 7 & 8 & 9 & 10 & Total & Skor \\
\hline 1 & Baiq Desi Milandan, M.Pd & 4 & 4 & 4 & 5 & 5 & 4 & 4 & 4 & 4 & 4 & 42 & A \\
\hline 2 & Islahudin, MPfis & 4 & 5 & 4 & 4 & 4 & 5 & 5 & 5 & 5 & 4 & 45 & A \\
\hline 3 & Linda Sekar Utami, M.Pfis & 4 & 4 & 4 & 4 & 4 & 4 & 4 & 4 & 4 & 4 & 40 & B \\
\hline 4 & Andinana Puil Sumarti S.Pd & 5 & 5 & 4 & 5 & 5 & 5 & 5 & 4 & 4 & 4 & 46 & A \\
\hline
\end{tabular}

Table 11. Hasil Validasi Kriteria Tampilan

\begin{tabular}{|c|l|c|c|c|c|c|c|c|c|c|c|c|}
\hline No & \multicolumn{1}{|c|}{ Nama ahli } & 1 & 2 & 3 & 4 & 5 & 6 & 7 & 8 & 9 & Total & Skor \\
\hline 1 & BaiqDesi Mlandari, M.Pd & 4 & 5 & 5 & 4 & 4 & 4 & 4 & 4 & 4 & 38 & A \\
\hline 2 & Islahudin,MPfis & 4 & 4 & 5 & 2 & 4 & 3 & 4 & 4 & 4 & 34 & B \\
\hline 3 & Linda Sekar Utami,MPfis & 4 & 5 & 5 & 2 & 4 & 4 & 5 & 5 & 3 & 37 & B \\
\hline 4 & Andriana Puii Sunarti,S.Pd & 4 & 4 & 5 & 4 & 5 & 5 & 5 & 5 & 5 & 42 & A \\
\hline
\end{tabular}

Table 12. Hasil Validasi Kriteria Teknis

\begin{tabular}{|c|l|c|c|c|c|c|c|c|c|c|c|c|}
\hline No & \multicolumn{1}{|c|}{ Nama ahli } & 1 & 2 & 3 & 4 & 5 & 6 & 7 & 8 & 9 & Total & Skor \\
\hline 1 & Baiq Desi Milandari, M.Pd & 3 & 3 & 4 & 4 & 4 & 4 & 4 & 3 & 4 & 33 & B \\
\hline 2 & Islahudin, M.Pfis & 5 & 5 & 5 & 4 & 4 & 4 & 4 & 4 & 4 & 39 & A \\
\hline 3 & Linda Sekar Utami, M.Pfis & 4 & 4 & 4 & 4 & 4 & 3 & 4 & 4 & 4 & 35 & B \\
\hline 4 & Andriana Puij Sumarti, S.Pd & 5 & 5 & 5 & 5 & 5 & 5 & 4 & 4 & 4 & 42 & A \\
\hline
\end{tabular}

\section{B. Metode Penelitian Tahap II}

Penggunaan media pembelajaran RUMFIS berbasis program matlab di SMP Negeri 2 Labuapi untuk meningkatkan motivasi belajar siswa pada mata pelajaran Fisika materi Suhu dan Kalor. Sebelum menerapkan media pembelajaran RUMFIS berbasis program matlab siswa mengisi angket motivasi belajar yang sebelumnya telah divalidasi. Angket yang telah diisi oleh siswa kemudian diolah untuk mengetahui besar motivasi siswa.

Motivasi belajar siswa diolah berdasarkan indikator masing-masing. Jumlah semua indikator adalah 4. Untuk indikator perhatian jumlahnya ada 3 dimana sebelum menggunakan RUMFIS berbasis program matlab nomor item 1 dengan presentase 56\%, nomor item 2 dengan presentase $50 \%$, serta nomor item 3 dengan presentase $53 \%$. Setelah penerapan peningkat nomor item 1 presentasenya menjadi $68 \%$, nomor item 2 presentasenya menjadi $72 \%$, serta nomor item 3 presentasenya menjadi $74 \%$. Kriteria peningkatan motivasi dikorelasikan dengan kriteria gain dimana diperoleh hasil peningkatan motivasi belajar siswa sebesar 0,39. Aspek motivasi belajar yang kedua adalah relevansi dengan jumlah 3 item sebelum dan sesudah dimana sebelum penerapan RUMFIS berbasis program matlab nomor item 1 dengan presentase $48 \%$, nomor item 2 dengan presentase $57 \%$, serta nomor item 3 dengan presentase $55 \%$. Setelah penerapan peningkat nomor item 1 presentasenya menjadi $71 \%$, nomor item 2 presentasenya menjadi $72 \%$, serta nomor item 3 presentasenya menjadi $72 \%$, dengan nilai gain sebenar 0,39. Dan Aspek motivasi belajar yang ketiga adalah kepercayaan diri dengan jumlah masing-masing 5 item sebelum dan sesudah dimana sebelum penerapan RUMFIS berbasis program matlab nomor item 1 dengan presentase $53 \%$, nomor item 2 dengan presentase 52\%, nomor item 3 dengan presentase $51 \%$, nomor item 4 dengan presentase $54 \%$, serta nomor item 5 dengan presentase $49 \%$. Setelah penerapan peningkat nomor item 1 presentasenya menjadi $63 \%$, nomor item 2 presentasenya menjadi $64 \%$, nomor item 3 presentasenya menjadi $73 \%$, nomor item 4 presentasenya menjadi $71 \%$, serta nomor item 5 presentasenya menjadi $74 \%$ dengan nilai gain sebenar 0,35 . Dan yang ke empat adalah kepuasan dengan jumlah 5 item, sebelum menggunakan RUMFIS berbasis program matlab nomor item 1 dengan presentase $47 \%$, nomor item 2 dengan presentase $52 \%$, nomor item 3 dengan presentase $50 \%$, nomor item 4 dengan presentase $49 \%$, serta nomor item 5 dengan presentase $50 \%$. Setelah penerapan peningkat nomor item 1 presentasenya menjadi $76 \%$, nomor item 2 presentasenya menjadi $74 \%$, nomor item 3 presentasenya menjadi $76 \%$, nomor item 4 presentasenya menjadi $78 \%$, serta nomor item 5 presentasenya menjadi $78 \%$, dengan nilai gain 0,53 .

Dalam pengukuran motivasi belajar siswa digunakan teknik analisis data berupa data kuantitatif, yang diperoleh peningkatan dengan menggunakan normalisasi gain untuk motivasi belajar berupa perhatian 0,39 dengan kriteria sedang, motivasi belajar relevansi 0,39 dengan kriteria sedang, motivasi belajar kepercayaan diri 0,35 dengan kriteria sedang, dan motivasi belajar kepuasan 0,53 dengan kriteria sedang. Peningkatan motivasi belajar secara klasikal juga berada pada kriteria sedang dengan normalisasi gain sebesar 0.43. Dengan demikian, hasil penelitian terhadap motivasi belajar siswa secara klasikal mengalami peningkatan motivasi belajar berada dalam kategori sedang. 
Berdasarkan penelitian yang telah dilakukan, media pembelajaran berbasis RUMFIS berbasis program matlab ini telah teruji keefektifannya dan mempunyai peningkatan motivasi belajar siswa di SMP Negeri 2 Labuapi.

\section{SIMPULAN DAN SARAN Kesimpulan}

Berdasarkan hasil penelitian dan pembahasan yang telah diuraikan sebelumnya maka dapat diambil kesimpulan-kesimpulan sebagai berikut bahwa:

1. Produk RUMFIS valid untuk meningkatkan motivasi belajar siswa pada hasil validasi dari 30 pertanyaan dengan 4 indikator terdapat 16 valid dan 14 tidak valid, terjadi peningkatan motivasi belajar siswa dengan menggunakan normalisasi gain untuk motivasi belajar berupa perhatian 0,39 dengan kriteria sedang, motivasi belajar relevansi 0,39 dengan kriteria sedang, motivasi belajar kepercayaan diri 0,35 dengan kriteria sedang, dan motivasi belajar kepuasan 0,53 dengan kriteria sedang.

2. Respon siswa kelas VII di SMP NEGERI 2 Labuapi terhadap RUMFIS berbasis program matlab adalah positif karena terdapat pada tingkat kualifikasi baik dengan peningkan gain 0,43 berada pada kriteria sedang.

3. RUMFIS berbasis program matlab dapat meningkatkan motivasi belajar Secara klasikal, motivasi belajar siswa mengalami peningkatan. Peningkatan motivasi secara jelas dibuktikan bahwa persentase motivasi peserta didik menggunakan media konvensional adalah sebanyak $51 \%$. Setelah penggunaan RUMFIS berbasis program matlab persentase motivasi belajar siswa mengalami peningkatan menjadi $72 \%$.

\section{Saran}

Berdasarkan penelitiaan yang telat $\cdots \cdots-\cdots$ kan, maka diberikan beberapa saran bc 59 ieliti selanjutnya, yaitu

1. RUMFIS berbasis program matlab yang dikembangkan dapat digunakan dengan baik, namun masih memiliki kekurangan baik dari segi pendidikan, tampilan, dan kualitas teknis. Hal ini dapat dijadikan pertimbangan bagi peneliti selanjutnya untuk mengembangkan media pembelajaran yang lebih sempurna lagi.

2. Hasil penelitian ini dapat digunakan oleh guruguru SMP sederajat sebagai salah satu media belajar dan sekaligus sumber belajar yang bersifat suplemen atau tambahan.

3. RUMFIS berbasis program matlab (fisika) ini dapat dikembangkan lagi dengan variasi desain dan gambar yang berbeda. Dapat juga dikembangkan pada materi lain untuk setiap pelajaran, kelas dan semester yang berbeda khususnya di sekolah menengah pertama (SMP).

4. RUMFIS berbasis program matlab ini dapat dikembangkan untuk semua mata pelajaran yang lain.

\section{DAFTAR PUSTAKA}

Away ,G. A. 2006. The Shortcut of Matlab Programming, Informatika, Bandung.

Azwar, S. 2015. Tes Prestasi. Yogyakarta: Pustaka Pelajar.

Abdullah, M. 2016. Fisika Dasar I. Bandung: Intitut Teknologi. Bandung.

Bahtiar. 2010. Fisika Dasar I. Yogyakarta: Kurnia Kalam Semesta.

Darma dkk, 2017. Pengembangan Buku Kerja Fisika Berbasis Konseptual pada

Konsep Suhu dan Kalor. Jurnal ilmiah penelitian dan pembelajaran fisika.UNAST dan UNP.

Emzir. 2014. Metodelogi Penelitian Pendidikan Kuantitatif \& Kualitatif. Jakarta:Rajawali Pers.

Fauzih, 2009. Penggunaan Program Matlab Sebagai Media Pembelajaran Fisika pada Materi Rangkaian Listrik. Institut Teknologi Bandung. Tesis.

Giancoli, D. C. 1999. Fisika Edisi Kelima Jilid 1. Jakarta: Erlangga.

Halliday, D. dkk, 1990. Dasar-Dasar Fisika Versi diperluas Jilid 1. Tanggerang: BINARUPA AKSARA Publisher.

Hake, R.R. (1998). Interactive-engagement versustraditional methods: A sixthousand-student survey of mechanics test data for introductory physics courses. American Journal of Physics 66, 64 (1998). 10.1119/1.18809.

Nababa, J. ML. 2016. Pemanfaatan media belajar berbasis program aplikasi

matlab untuk meningkatkan hasil belajar siswa menganalisis rangkaian listrik arus searah/ listrik dinamis kelas $x$ teknik instalasi tenaga listrik smk negeri 1 balige tahun ajaran 2015/2016. Universitas Negeri Medan: Skripsi.

Rahayu, S. A. 2016. Visual Konsep Persamaan kuadrat Melalui Program Graphical User Interface (GUI) Matleb. Universitas Jember: Tesis.

Riduwan, 2014. Metode dan Teknik Menyusun Proposal Penelitian. Bandung: Alfabeta.

Ropita, D. 2015. Pengembangan Buletin Fisika Berbentuk Buku Saku Untuk Meningkatkan Motivasi Belajar Siswa Sma Model Nurul Jannah Kelas X Materi 
Suhu Dan Kalor Tahun Pelajaran 2015/2016. UMMAT.

Skripsi: Tidak di Publikasikan.

Sari, Ika M. 2009. Membangun Multimedia Interaktif Pokok Bahasan Perkembangan Teori Atom dengan Menggunakan GUI Matlab 7.0. Institut

Teknologi Bandung. Tesis.

Sukmadinata, S. 2016. Metodelogi Penelitian. Bandung: PT. Remaja Rosidataria.

Sugiyono, 2016. Metodelogi Penelitian Pendidikan Pendekatan Kuantitatif,Kuanlitatif dan $R \& D$. Bandung: Alfabeta.

Sitanggang, F.F. 2016 . Rancang bangun modul pembelajaran berbasis matlab dengan trainer pada mata pelajaran Dasar dan pengukuran listrik. Universitas Negeri Medan: Skripsi.

Sa'diyah, H dan I.G.P .A. Buditjahjanto, 2016. Pengembangan GUI Designer Matlab Sebagai Media Pembelajaran pada Pokok Bahasan Teknik Pengkodean Siyal di Jurusa Teknik Elektron UNESA. Jurnal pendidikan Teknik Elektron. UNESA.

Sucipto, A. A dan Bambang S. 2016. Pengembangan Media Pembelajaran Menggunakan GUI Matlab pada Poko Bahasan Modulasi Analog dan Digital Kelas XI TAV SMK Negeri 1 Sidoarjo. Jurnal pendidikan Teknik Elektron.UNESA

Tipler, P. A. 1998. Fisika untuk Sains dan Teknik. Jakarta: Erlangga.

Uno, Hamzah. B. 2016. TeoriMotivasi dan Pengukuran Analisis di Bidang Pendidikan. Jakarta: Bumi Aksara.

Winarno, M. E. 2018. Metodelogi Penelitian dalam Pendidikan Jasmani.Cetakan I. Malang: Universitas Negeri Malang. 